\title{
Note on Contributors
}

Graham Douglas graduated in chemistry and became interested in astrological research after reading Michel Gauquelin, and then meeting John Addey in 1977. An interest in anthropology and symbolism led to the work of Levi-Strauss, Mary Douglas, Marshall Sahlins and Georges Dumezil. He has published 25 articles on empirical research into astrology in the journal Correlation, and on the CURA website, as well as three academic studies of astrological symbolism in the journal Semiotica (1997-99), and the essay, 'Physics, Astrology and Semiotics' (1983), and contributed to the Radical Astrology Papers (1986). Recently, he has returned to statistical research on the Gauquelin database, from the perspective of classical astrology, well as offering more clues for how solar and geomagnetic influences may play a part in the Gauquelin Effect.

grammino7@hotmail.com

Scott E. Hendrix holds a $\mathrm{PhD}$ in medieval history from the University of Tennessee (USA) and is currently an Assistant Professor of History at Carroll University in Waukesha, WI (USA). He has written on the historical development of astrology in the medieval Muslim crescent as well as the Latin Christian West, with his most recent work being How Albert the Great's Speculum astronomiae was Interpreted and Used by Four Centuries of Readers: A Study in Late Medieval Medicine, Astronomy and Astrology (Lewiston, NY: The Edwin Mellen Press, 2010).

shendrix@carrollu.edu

Luis Vilhena studied at the Instituto da Filosofia e Ciências Sociais do Universidade Federal do Rio de Janeiro, and was Professor of Anthropology at the State University and at the Catholic Pontificial University, both in Rio de Janeiro at the time of his death in 1997. He is the author of Projeto e Missão: O Movimento Folklorico Brasileiro 194764, a definitive study of the history of folklore studies in Brazil, analyzing the tensions and intellectual currents in play during a period of social transition between WW2 and the military dictatorship of 1964 . $O$ Mundo da Astrologia was based on his Master's thesis. More biographical information can be found (in Portuguese) at:

http://luisrodolfovilhena.googlepages.com/home 
Mark Williams read Classics and English at Oxford, followed by graduate work in Celtic Studies. His first book, Fiery Shapes: Celestial Portents and Astrology in Ireland and Wales, 700-1700 is forthcoming from Oxford University Press in August 2010. He is currently a Research Fellow at Peterhouse Cambridge, where he teaches literature in Middle English, the Celtic languages, and Latin. At present he is working on a cultural history of the gods of Irish mythology.

maw81@hermes.cam.ac.uk 